\title{
Turmeric (Curcuma longa Linn.) as a phytogenic growth promoter alternative for antibiotic and comparable to mannan oligosaccharides for broiler chicks
}

\author{
Youssef A. Attia ${ }^{a *}$, Mohammed A. Al-Harthia, Saber S. Hassan ${ }^{b}$
}

\begin{abstract}
This work aimed at investigating the potential as a growth enhancer of different dietary concentrations of turmeric (Curcuma longa Linn.) as an alternative to oxytetracyline (OTC) as antibiotic and as comparable to mannan oligosaccharide for broiler chicks. A total of $\mathbf{2 5 2}$ Hubbard broiler chicks at one day of age were distributed randomly in a straight run experimental design among six treatments, each replicated seven times, with six unsexed chicks per replicate. The basal diet was administered without supplements (control group) or supplemented with turmeric at 0.5 , 1, and $2 \mathrm{~g} / \mathrm{kg}$ diet, or with mannan oligosacride (MOS) at $1 \mathrm{~g} / \mathrm{kg}$ feed or with OTC at $50 \mathrm{mg} / \mathrm{kg}$ feed. Growth performance, carcass characteristics, meat quality traits, blood biochemical constituents, antioxidant status and red blood cell (RBCs) were investigated. Turmeric supplementation at $\mathbf{1 ~} \mathbf{g} / \mathbf{~ k g}$ feed significantly improved feed conversion ratio (FCR) and European production index compared to the control group and MOS groups. The results indicated that turmeric can be used at $1 \mathrm{~kg} / \mathrm{t}$ feed as a phytogenic feed additive as an alternative to OTC or MOS without negative effects on the productive and economic traits of broilers. There were no differences from using OTC and MOS, while there was an increase in the European production efficiency index and the broilers' health status.
\end{abstract}

KEY WORDS: Turmeric, Antibiotic, Prebiotics, Carcass traits, Meat quality, Blood biochemical, Blood biochemistry, Broiler.

\section{RESUMEN}

Este trabajo se realizó para investigar el potencial como promotor del crecimiento de diferentes concentraciones dietéticas de cúrcuma (Curcuma longa Linn.) como una alternativa a los antibióticos y oxitetraciclina y comparable a oligosacáridos mannan (MOS) para pollos de engorda. Un total de 252 pollos Hubbard de un día de edad se distribuyeron al azar en un diseño experimental de seis tratamientos, siete repeticiones y con seis pollos sin sexar por repetición. La dieta basal se administró sin suplementos (grupo control) o complementada con cúrcuma en dosis de $0.5,1$ y 2 g/ kg de dieta, o con 1 g/ kg de alimento de oligosacárido mannan, o con oxitetraciclina $50 \mathrm{mg} / \mathrm{kg}$ de alimento. Se evaluó el crecimiento, características de la canal, características de calidad de carne, constituyentes bioquímicos sanguíneos, estado antioxidante y glóbulos rojos. La suplementación de cúrcuma en $1 \mathrm{~g} / \mathrm{kg}$ alimento significativamente mejoró la tasa de conversión alimenticia y el Índice de Producción Europea en comparación con el grupo control y grupo MOS. Los resultados indican que la cúrcuma puede usarse en $1 \mathrm{~kg} / \mathrm{t}$ de alimento como una alternativa a oxitetraciclina o MOS sin efectos negativos sobre los rasgos productivos y económicos de pollos de engorda. No hubo diferencias de uso entre oxitetraciclina y MOS, mientras que con cúrcuma hubo un aumento en el índice de eficiencia de la producción europea y el estado de salud de los pollos.

PALABRAS CLAVE: Cúrcuma, Antibióticos, Probióticos, Calidad de canal, Calidad de carne, Química sanguínea, Pollos.

Received December 7, 2015. Accepted March 14, 2016.

a Arid Land Agriculture Department, Faculty of Meteorology, Environment, and Arid Land Agriculture, King Abdulaziz University, Jeddah, Saudi Arabia. P.O. Box 80208, Jeddah 21589, Saudi Arabia Tel:+966568575961, fax:+9666952364

${ }^{\mathrm{b}}$ Animal and Poultry Production Department, Faculty of Agriculture, Damanhour University, Egypt.

* Corresponding author: Youssef A. Attia. yaattia@kau.edu.sa.

Funding agent: This project was funded by the Deanship of Scientific Research (DSR), King Abdulaziz University, J eddah, under grant No. (G-1436/155/205). The authors, therefore, acknowledge with thanks DSR technical and financial support. 


\section{INTRODUCTION}

In the last few decades, antibiotic residuals and the development of bacterial strains resistant to antibiotics have become a problem ${ }^{(1)}$ due to the addition of antibiotics in animal feed formulations ${ }^{(2,3,4)}$. However, the prohibition of the use of antibiotics in animal feed in Europe in 2006 to improve the safety and security of the food chain caused significant health problems in poultry, such as increasing the incidence of intestine necrotic enteritis and clostridia. These in turn caused major complications related to decreasing animal welfare and increasing economic losses ${ }^{(4,5)}$. Hence prebiotics, probiotics, synbiotics, herbs, spices and essential oils has been investigated as an alternative to antibiotics because of their antibacterial, antioxidant, digestive and metabolic enhancing effects ${ }^{(6)}$.

Botanical compounds have been shown to be potential alternatives to antibiotics for poultry production $^{(7,8,9)}$. Turmeric is a member of the Zingiberaceae family. It is mainly utilized in the food industry to enhance the palatability, preservation and appearance of food. Tumeric contains different bioactive compounds, such as curcumin, demethoxycurcumin, bisdemethoxycurcumin and tetrahydrocurcuminoids ${ }^{(10,11,12)}$. These bioactive compounds have antioxidant, anti-inflammatory and nematocidal activities ${ }^{(10,13,14,15)}$, protective effects against mutagenicity and hepatocarcinogenicity induced by aflatoxin ${ }^{(2,16)}$ and against coccidiosis ${ }^{(5,17,18)}$. In the literature, the effects of turmeric supplementation between 0 to $10 \mathrm{~g} / \mathrm{kg}$ on chicken performance have been inconclusive. For example, broilers fed diets supplemented with turmeric at 5 $\mathrm{g} / \mathrm{kg}$ feed exhibited improved performance but did not affect serum total protein, albumin, globulin, ALKP, ALT and AST enzymes ${ }^{(1,6,19)}$. On the other hand, turmeric powder did not significantly affect growth performance or the carcass yield of broiler chickens $^{(9,12,20)}$. Turmeric powder at 0.6 and 0.9 $\mathrm{g} / \mathrm{kg}$ alleviated the negative effect of aflatoxin $\mathrm{B}_{1}$ on serum total protein, albumin and globulin, boosted antioxidant defense enzymes, e.g. catalase and superoxide dismutase, and decreased $\mathrm{MDA}^{(2)}$. The levels of liver enzymes (ALT and ALKP) were substantially reduced by feeding broilers turmeric powder at $5 \mathrm{~g} / \mathrm{kg}^{(21)}$.

Prebiotics are also possible alternatives, particularly mannan oligosaccharides (MOS) derived from Saccharomyces cerevisiad ${ }^{22,23)}$. The mode of action of MOS involves supplying intestinal microflora by nutrients (as prebiotics) and inhibiting the attachment of pathogenic bacteria, i.e. E. coli and Salmonella enteritidis, to the intestinal mucosa by binding the mannose receptors on the type 1 fimbriae ${ }^{(22)}$. The positive effect of MOS on broiler performance was already reviewed $^{(22)}$.

Oxytetracyclines (OTC) are broad-spectrum bacteriostatic agents derived from the bacteria Streptomyces. Oxytetracyclines prevent bacteria from multiplying while the host animal's immune system deals with the original infection. The recommended dose is 5 to $50 \mathrm{~g} / \mathrm{t}$ feed as a continuous feed additive. In the literature, oxytetracyclines have been used for the amelioration of the growth of broilers, but the

Table 1. Fatty acid (FA) composition as percentage of fatty acids and antioxidants indices of turmeric

\begin{tabular}{lcc}
\hline Fatty acid & $\begin{array}{c}\text { As a \% of } \\
\text { FA }\end{array}$ & $\begin{array}{c}\text { As a \% of } \\
\text { FA }^{2}\end{array}$ \\
\hline C6:0 & 0.166 & --- \\
C8:0 & 0.039 & --- \\
C10:0 & 0.347 & --- \\
Undecanoic acid, C11:0 & 0.099 & --- \\
Tridecanoic acid, C13:0 & 0.282 & --- \\
Myristic acid, C14:0 & 0.94 & --- \\
Pentadecenoic acid, C15:1 & 11.29 & 4.04 \\
Palmtioleic C16:1 & 28.11 & 32.50 \\
Palmitic acid, C16:0 & $8 . .60$ & 9.76 \\
Heptadecenoic C 17:1 & 19.15 & 20.98 \\
Linolenic C 18.3 & --- & 6.01 \\
Linoleic acid, C18:2c & 15.70 & 18.63 \\
Oleic acid, C18:1 & 14.1 & 8.08 \\
Stearic acid, C18:0 & 0.103 & --- \\
Arachidic acid, C20:0 & 0.16 & --- \\
SFA & 10.73 & 9.76 \\
MUFA & 72.65 & 61.66 \\
PUFA & 15.70 & 24.64 \\
UFA & 89.35 & 86.30 \\
SFA/UFA ratio & 0.120 & 0.113 \\
Antioxidant activity inhibition, \% & 60.38 & ---- \\
Total phenolic compounds, mg/kg & 14.25 & --- \\
\hline & & \\
\hline
\end{tabular}

${ }_{1}$ Represents the present sample of turmeric ${ }^{2}$ according to Radwan ${ }^{(28)}, \mathrm{SFA}=$ Saturated fatty acids, MUFA= Mono unsaturated fatty acids, PUFA= polyunsaturated fatty acids, UFA= Unsaturated fatty acids. 
results have been contradictory ${ }^{(24,25)}$. Thus this research aims to investigate the growth promoting effect of turmeric (Curcuma longa Linn.) and to compare it to OTC and MOS on growth performance, carcass characteristics, meat quality, serum biochemical constituents and health status during the $1^{\text {st }}$ through $35^{\text {th }}$ days of age of broiler chickens.

\section{MATERIAL AND METHODS}

\section{Source of turmeric, fatty acid profiles and antioxidant indices}

Turmeric purchased from the local market in a powder form was used in this experiment. The chemical analyses of the experimental diets were according to $A O A C^{(26)}$, meanwhile, metabolizable energy value was calculated using the equation for vegetable/plant feedstuffs according to Janssen ${ }^{(27)}$. The fatty acids profile analysed according to Radwan (28) (Table 1) after the extraction of lipids ${ }^{(26)}$. The total phenolic contents according to Balinsky et $a{ }^{(29)}$ and the antioxidant activity (\%) inhibition, determined to Benzie et al methodology ${ }^{(30)}$.

\section{Chicks, diets and experimental design}

A total of 252 Hubbard broiler chicks $1 \mathrm{~d}$ of age were used in this experiment. They were fed the experimental diets (Table 2) according to a two-phase feeding system, with a starter-grower diet from d 1 to 27 and a finisher diet from d 28 to 35. The chicks were distributed randomly in a complete randomized design among six treatments. Each was replicated seven times with six unsexed chicks per replicate. The basal diet was

Table 2. Diets composition and nutrient profiles of the experimental diets percentage as fed basis

\begin{tabular}{|c|c|c|c|c|c|c|c|c|}
\hline \multirow{2}{*}{ Ingredients/ profiles } & \multicolumn{4}{|c|}{ Starter-grower diets $1-27 \mathrm{~d}$ of age $(\mathrm{kg} / \mathrm{t})$} & \multicolumn{4}{|c|}{ Finisher diets $28-35 \mathrm{~d}$ of age $(\mathrm{kg} / \mathrm{t})$} \\
\hline & 0 & 0.5 & 1.0 & 2.0 & 0 & 0.5 & 1.0 & 2.0 \\
\hline Maize & 508 & 507.5 & 507 & 506 & 600 & 599.5 & 599 & 598 \\
\hline Full fat soybean & 80 & 80 & 80 & 80 & 100 & 100 & 100 & 100 \\
\hline Soybean meal & 335 & 335 & 335 & 335 & 230 & 230 & 230 & 230 \\
\hline Vegetable oil blend & 40 & 40 & 40 & 40 & 37 & 37 & 37 & 37 \\
\hline Turmeric powder & 0.0 & 0.5 & 1.0 & 2.0 & 0.00 & 0.5 & 1.0 & 2.0 \\
\hline Sodium chloride & 3.0 & 3.0 & 3.0 & 3.0 & 3.0 & 3.0 & 3.0 & 3.0 \\
\hline Dl- methionine & 1.5 & 1.5 & 1.5 & 1.5 & 1.0 & 1.0 & 1.0 & 1.0 \\
\hline L-lysine & 1.0 & 1.0 & 1.0 & 1.0 & 1.0 & 1.0 & 1.0 & 1.0 \\
\hline Dicalcium phosphate & 18.5 & 18.5 & 18.5 & 18.5 & 15.0 & 15.0 & 15.0 & 15.0 \\
\hline Limestone & 10 & 10 & 10 & 10 & 10 & 10 & 10 & 10 \\
\hline Vit. + Min. mixture 1 & 3.0 & 3.0 & 3.0 & 3.0 & 3.0 & 3.0 & 3.0 & 3.0 \\
\hline Total & 1000 & 1000 & 1000 & 1000 & 1000 & 1000 & 1000 & 1000 \\
\hline \multicolumn{9}{|c|}{ Calculated $^{2}$ and chemical composition ${ }^{3}(\mathrm{~g} / \mathrm{kg})$} \\
\hline ME MJ/kg diet² & .1297 & .1297 & .1297 & .1297 & .1346 & .1346 & .1346 & .1346 \\
\hline Dry matter ${ }^{3}$ & 897 & 895 & 898 & 896 & 895 & 897 & 898 & 891 \\
\hline Crude protein ${ }^{3}$ & 222 & 223 & 220 & 221 & 189 & 187 & 189 & 187 \\
\hline Calcium $^{2}$ & 9.2 & 9.2 & 9.2 & 9.2 & 8.2 & 8.2 & 8.2 & 8.2 \\
\hline Inorganic phosphorus ${ }^{2}$ & 4.9 & 4.9 & 4.9 & 4.9 & 4.1 & 4.1 & 4.1 & 4.1 \\
\hline Methionine+cystine ${ }^{2}$ & 8.5 & 8.5 & 8.5 & 8.5 & 7.4 & 7.4 & 7.4 & 7.4 \\
\hline Lysine $^{2}$ & 13.0 & 13.0 & 13.0 & 13.0 & 11.0 & 11.0 & 11.0 & 11.0 \\
\hline Crude fibre ${ }^{3}$ & 52.3 & 52.3 & 52.3 & 52.3 & 56.5 & 54.7 & 55.5 & 57.5 \\
\hline Crude fat ${ }^{3}$ & 88.3 & 88.3 & 88.3 & 88.3 & 89.1 & 87.1 & 88.1 & 89.3 \\
\hline $\mathrm{Ash}^{3}$ & 85.3 & 84.3 & 83.7 & 86.4 & 91.2 & 90.8 & 88.5 & 89.0 \\
\hline
\end{tabular}

1Vit+Min mix. provides per kilogram of the diet: Vit. A, $12000 \mathrm{IU}$, vit. E (dl-a-tocopheryl acetate) $20 \mathrm{mg}$, menadione $2.3 \mathrm{mg}$, Vit. D3, $2200 \mathrm{ICU}$, riboflavin $5.5 \mathrm{mg}$, calcium pantothenate $12 \mathrm{mg}$, nicotinic acid $50 \mathrm{mg}$, Choline $250 \mathrm{mg}$, vit. B12 $10 \mu \mathrm{g}$, vit. B6 $3 \mathrm{mg}$, thiamine $3 \mathrm{mg}$, folic acid $1 \mathrm{mg}$, d-biotin $0.05 \mathrm{mg}$. Trace mineral (mg/ kg of diet): Mn $80 \mathrm{Zn} \mathrm{60,} \mathrm{Fe} \mathrm{35,} \mathrm{Cu} \mathrm{8,} \mathrm{and} \mathrm{Selenium} 0.1 \mathrm{mg}$. 
formulated to be isocaloric and isonitrogenous and to meet the nutrient requirements ${ }^{(31)}$. The basal diet was administered without the tested supplements (the control group) or supplemented with turmeric at 0.5 (T_0.5), 1 ( $\left.T_{-} 1\right)$, and 2 (T_2) $\mathrm{g} / \mathrm{kg}$ diet. The concentrations of turmeric supplementation was chosen based in previous studies $^{(12,20,21)}$ in which 0 to $10 \mathrm{~g} / \mathrm{kg}$ was included in broiler diets with inconclusive results. The basal diet was also supplemented with mannan oligosaccharides (MOS; Altech Inc., Nicholasville, $\mathrm{KY}, \mathrm{USA}$ ) at $1 \mathrm{~g} / \mathrm{kg}$ diet or oxytetracycline (OTC) at $50 \mathrm{mg} / \mathrm{kg}$ diet. OTC is a broad-spectrum bacteriostatic agent derived from the bacteria Streptomyces. The recommended dose is 5 to 50 $\mathrm{g} / \mathrm{t}$ feed as a continuous feed additive. Terramycin (OTC) is a registered trademark of Pfizer, Inc., USA. It is US FDA NADA (new animal drug application) \#95-143, approved by the FDA 7870000 101-9010-07 and licensed to Phibro Animal Health Corporation for OTC HCl.

\section{Broilers husbandry}

Chicks were kept in battery brooders $(40 \times 45 \times 60 \mathrm{~cm})$ under similar managerial and hygienic conditions in semi-opened housing. Water and mash feeds were offered ad libitum. The brooding temperature was 34,32 and $30 \circ \mathrm{C}$ during the $1^{\text {st }}, 2^{\text {nd }}$ and $3^{\text {rd }}$ wk of age, respectively. During 21 to $35 \mathrm{~d}$ of age, the average ambient temperature and relative humidity $(\mathrm{RH})$ were $30 \pm$ $3^{\circ} \mathrm{C}$ to $45 \pm 4 \%$, respectively. The light-dark cycle was 23:1.

\section{Data collection}

Body weight was recorded at the $1^{\text {st }}, 14^{\text {th }}, 27^{\text {th }}$ and $35^{\text {th }} \mathrm{d}$ of age; body weight gain, feed intake and the feed conversion ratio (FCR) were calculated for the periods 1-14, 1-27, and 1-35 d of age. At $35 \mathrm{~d}$ of age, seven chickens from each treatment representing all replicates were randomly taken and slaughtered to determine their carcass characteristics. In addition, the lymphoid organs, including the thymus, spleen and bursa of Fabricius, were removed and weighed. Meat quality traits ( $n=7$ samples/treatment) represented all replicates, such as chemical composition (dry matter, protein, lipid and ash) and physical characteristics $(\mathrm{pH}$, colour of meat, water holding capacity [WHC] and tenderness) were carried out as previously reported ${ }^{(32)}$.
At d 35 of age, seven blood samples were collected in both not-heparinized and heparinized tubes from each treatment represented all treatment replicates. The serum was separated by centrifugation at $1,500 \mathrm{xg}$ for $10 \mathrm{~min}$ at $4{ }^{\circ} \mathrm{C}$ and stored at $-18^{\circ} \mathrm{C}$ until analysis. The selected serum biochemical profile such as serum total protein and albumin concentrations $(\mathrm{g} / \mathrm{dL})$, alanine aminotransferase (ALT) and aspartate aminotransferase (AST), ( $\mu / L)$, alkaline phosphatase (ALKP) enzymes, total antioxidant capacity (TAC) as an indicator of antioxidant status, and malnodialdehyde (MDA as a biomarker for lipid peroxidation respectively were determined using commercial diagnostic kits (Diamond Diagnostics Company, Cairo, Egypt) ${ }^{(32,33)}$. Globulin concentration $(\mathrm{g} / 100 \mathrm{~mL}$ ) was calculated as the difference between total protein and albumin. Red blood cell (RBCs) characteristics, including haemoglobin (Hgb), packed cell volume (PCV), mean corpuscular haemoglobin $(\mathrm{MCH})$, mean corpuscular volume (MCV) and mean corpuscular haemoglobin concentration (MCHC), were measured as previously cited ${ }^{(32,33)}$. Haemagglutination (HINDV) inhibition for New Castle disease virus was determined according to Snyder et $a k^{(34)}$.

Upon necropsy, the intestine was removed, thoroughly washed with a physiological saline $(0.9 \% \mathrm{NaCl})$ solution, blotted on filter paper and then buffered with formalin $10 \%$. The fixed specimens were processed using a conventional paraffin embedding technique. From the prepared paraffin blocks, $5 \mathrm{~mm}$ thick sections were obtained and stained with haematoxylin and eosin for light microscopic examination ${ }^{(35)}$. In order to determine the length of the villi, 5 villi were measured on each segment for all groups. The villi lengths were measured from their base upwards to the end of the villus. The morphometric measurements were taken in a binocular microscope equipped with a clear Nikon camera and coupled with an imageanalysing system from Optika ${ }^{(36)}$.

\section{Statistical analysis}

Data were analysed using the SAS software program $^{(37)}$, using a completely randomized design, considering the replicate as the experimental unit according to the following model:

$$
Y_{i, j}=\mu+T_{i}+\varepsilon_{i(j)}
$$


With $Y_{i, j}$ being any observation for which $X_{1}=i$ ( $i$ and $j$ denote the level of the factor and the replication within the level of the factor, respectively); $\mu=$ general location parameter; $T_{i=}$ is the effect of having treatment level $/ ; \varepsilon i(j)=$ is the random error.

Mean differences were tested by the Tukey's studentized test ${ }^{(37)}$ using $P \leq 0.05$; although when $P$ value was great than 0.05 and less than 10 was reported as trend. Before analysis, all percentages were converted to arc sin to normalize data distribution.

\section{RESULTS}

Chemical composition, fatty acids, antioxidant activity percentage inhibition and total phenolic compounds

Chemical composition of turmeric showed $89.7 \%$ dry matter, $5.8 \%$ crude protein, $4.7 \%$ ether extract, $4.2 \%$ ash $3.5 \%$ crude fiber and $71.5 \%$ nitrogen free extract and calculated ME value was found to be 3,664 kcal/ $\mathrm{kg}$ turmeric. The results, as displayed in Table 1 , describe the fatty acids content of turmeric, antioxidant activity inhibition and total phenolic compounds. The results indicate that linoleic acid is the dominant polyunsaturated fatty acid and palmitoleic acid is the dominant monounsaturated fatty acid. These indicate that turmeric is a good source of unsaturated fatty acids. The antioxidant activity inhibition and total phenolic compounds are 60.38 $\%$ and $14.25 \mathrm{mg} / \mathrm{g}$, revealing a potential antioxidant activity.

\section{Growth performance}

Data for broiler performance are shown in Table 3. The results showed that different supplements did not significantly affect BWG of chickens during different experiment period except for a trend for greater $(P \leq 0.089)$ growth of T_0.5, and the MOS groups during $\mathrm{d} 15-27$ and $\mathrm{T} 0 . \overline{5}$ and T_1 ( $P \leq 0.095)$ during the whole experimental period (d 1-35 of age) in comparison to the control group, T_2 group and OTC groups and the control group, $\overline{\mathrm{T}} 2$ group, MOS and the OTC groups, respectively.

Table 3. Growth performance of broiler chickens fed diets supplemented with different concentrations of turmeric, mannanoligosacchride and oxytetracycline

\begin{tabular}{|c|c|c|c|c|c|c|c|c|}
\hline \multirow{2}{*}{ Criteria } & \multirow{2}{*}{ Control } & \multicolumn{3}{|c|}{ Curcumin $\mathrm{g} / \mathrm{kg}$ diet } & \multirow{2}{*}{ MOS } & \multirow{2}{*}{ OTC } & \multirow{2}{*}{ SEM } & \multirow{2}{*}{$P$-value } \\
\hline & & 0.5 & 1 & 2 & & & & \\
\hline \multicolumn{9}{|c|}{ Body weight and body weight gain, $g$} \\
\hline Body weight at $1 \mathrm{~d}$ & 46 & 46 & 48 & 47 & 45 & 46 & 1.01 & 0.524 \\
\hline BWG $1-14 \mathrm{~d}$ of age & 386 & 352 & 376 & 341 & 377 & 347 & 13.9 & 0.139 \\
\hline BWG $15-27 \mathrm{~d}$ of age & 837 & 954 & 882 & 829 & 905 & 836 & 34.1 & 0.089 \\
\hline BWG $28-35 \mathrm{~d}$ of age & 495 & 527 & 580 & 565 & 510 & 599 & 40.1 & .0401 \\
\hline BWG $1-35 \mathrm{~d}$ of age & 1718 & 1833 & 1838 & 1735 & 1792 & 1781 & 34.2 & 0.095 \\
\hline \multicolumn{9}{|c|}{ Feed intake, g/chick/ period } \\
\hline 1-14 d of age & $646^{a}$ & $607^{a b}$ & $560^{\mathrm{ab}}$ & $511^{b}$ & $649^{a}$ & $549 a b$ & 23.6 & 0.001 \\
\hline $15-27 \mathrm{~d}$ of age & $1495^{a b c}$ & $1652^{a}$ & $1465^{\mathrm{abc}}$ & $1416^{b c}$ & $1597 a b$ & $1316^{c}$ & 52.8 & 0.001 \\
\hline $28-35 d$ of age & 994 & 1093 & 1072 & 1002 & 1045 & 1252 & 77.6 & 0.225 \\
\hline $1-35 \mathrm{~d}$ of age & $3135^{\mathrm{ab}}$ & $3352^{a}$ & $3097^{a b}$ & $2929 \mathrm{~b}$ & $3292^{\mathrm{a}}$ & $3118^{\mathrm{ab}}$ & 73.3 & 0.005 \\
\hline \multicolumn{9}{|c|}{ Feed conversion ratio, $\mathrm{kg}$ feed/kg gain } \\
\hline 1-14 d of age & $1.67 \mathrm{ab}$ & $1.72^{\mathrm{a}}$ & $1.49 c$ & $1.50^{c}$ & $1.72^{\mathrm{a}}$ & $1.58^{\mathrm{bc}}$ & 0.022 & 0.001 \\
\hline $15-27 \mathrm{~d}$ of age & $1.78^{a}$ & $1.74^{\mathrm{ab}}$ & $1.66^{\mathrm{ab}}$ & $1.71^{\mathrm{ab}}$ & $1.77^{\mathrm{a}}$ & $1.59^{b}$ & 0.038 & 0.012 \\
\hline $28-35 d$ of age & 2.01 & 2.09 & 1.85 & 1.74 & 2.04 & 2.19 & 0.109 & 0.076 \\
\hline $1-35 \mathrm{~d}$ of age & $1.82^{\mathrm{a}}$ & $1.83^{a}$ & $1.68^{b}$ & $1.69 \mathrm{~b}$ & $1.84^{\mathrm{a}}$ & $1.75^{\mathrm{ab}}$ & 0.021 & 0.001 \\
\hline \multicolumn{9}{|c|}{ Survival rate and European production efficiency index (EPEI) } \\
\hline Survival rate, $\%$ & 100 & 100 & 100 & 100 & 100 & 100 & 0 & ND \\
\hline EPEI & $262^{b}$ & $279 \mathrm{ab}$ & $303^{a}$ & $286^{a b}$ & $271^{b}$ & $282^{\mathrm{ab}}$ & 5.98 & 0.001 \\
\hline
\end{tabular}

MOS= Mannoligaosacchride; OTC=Oxytiteracycline; BWG= Body weight gain; SEM= Standard error of means.

$a, b, c$ Differences among means within a column within each factor not sharing similar superscripts are significant $(P<0.05)$, 
Feed intake during the different experimental periods was significantly affected by the different treatments. During d 1-14 of age, the T_ 2 group consumed significantly less feed than the control and MOS groups. During d 15-27 of age, the T_2 and OTC groups reduced feed intake in comparison to the T 0.5 group. In addition, OTC groups reduced feed intake in comparison to the MOS group. For the 1-35 d period, the T_2 group significantly decreased feed intake in comparison to the T_0.5 and MOS groups.

During most of the experimental periods, the different supplements significantly affected FCR. During d 1-14 of age, the T_1, T_2 and OTC groups significantly improved FCR in comparison to the other groups, but the T_1 and T_2 groups had more favorable effects than the OT' $\bar{C}$ group as the difference between OTC and control group was not significant. During d 15-27 of age, the OTC group significantly improved FCR in comparison to most of the experimental groups except for the T0.5, T_1 and T_2 groups. During d 28-35 of age, there was a trend for improved FCR of groups on T_1 and T_2 in comparison to the other experimental groups. For the whole period, the T_ 1 and T_ 2 groups significantly boosted FCR in comparison to the other groups except for OTC.

The survival rate was $100 \%$ in the different experiment groups. The European Production Efficiency Index of the T_ 1 group was significantly higher than that of the control and MOS groups. Other groups exhibited intermediate values.

\section{Carcasses characteristics and inner body organs}

The results for carcass traits, relative weight of internal organs, chemical composition and physical parameters of meat are presented in Table 4. Most of the traits were significantly

Table 4. Carcass characteristics, inner body organs and meat quality of broiler chickens fed diets supplemented with different concentrations of turmeric, mannanoligosacchride and oxytetracycline

\begin{tabular}{|c|c|c|c|c|c|c|c|c|}
\hline \multirow{2}{*}{ Criteria } & \multirow{2}{*}{ Control } & \multicolumn{3}{|c|}{ Curcumin g/kg diet } & \multirow{2}{*}{ MOS } & \multirow{2}{*}{ OTC } & \multirow{2}{*}{ SEM } & \multirow{2}{*}{$P$ value } \\
\hline & & 0.5 & 1 & 2 & & & & \\
\hline \multicolumn{9}{|c|}{ Carcass characteristics and inner body organs } \\
\hline Dressing, $\%$ & $72.7^{a}$ & $68.1^{b}$ & $69.4^{\mathrm{ab}}$ & $69.9 \mathrm{ab}$ & $68.7^{\mathrm{ab}}$ & $66.6^{b}$ & 0.951 & 0.006 \\
\hline Abdominal fat, $\%$ & 0.759 & 0.715 & 0.670 & 0.634 & 0.544 & 0.673 & 0.091 & 0.654 \\
\hline Proventiculus, $\%$ & $0.582^{\mathrm{a}}$ & $0.495^{a b}$ & $0.379 b$ & $0.532^{\mathrm{ab}}$ & $0.604^{a}$ & $0.505^{a b}$ & 0.056 & 0.010 \\
\hline Gizzard,\% & $1.38^{\mathrm{a}}$ & $1.32^{\mathrm{a}}$ & $0.889 b$ & $1.25^{\mathrm{a}}$ & $1.11^{\mathrm{ab}}$ & $1.15^{\mathrm{ab}}$ & 0.079 & 0.005 \\
\hline Liver,\% & 2.36 & 2.23 & 2.16 & 2.25 & 2.34 & 2.48 & 0.111 & 0.422 \\
\hline Heart, $\%$ & $0.540^{a}$ & $0.352^{b}$ & $0.430^{a b}$ & $0.533^{a}$ & $0.484^{a b}$ & $0.450^{a b}$ & 0.038 & 0.022 \\
\hline Pancreas, $\%$ & 0.283 & 0.274 & 0.214 & 0.253 & 0.299 & 0.228 & 0.019 & 0.039 \\
\hline Intestinal,\% & 7.93 & 8.53 & 8.13 & 8.97 & 7.65 & 7.99 & 0.451 & 0.332 \\
\hline Intestinal villi length, $\mu \mathrm{m}$ & $1261^{c}$ & $1435^{b}$ & $1406^{\mathrm{b}}$ & $1289^{b}$ & $1255^{c}$ & $1806^{a}$ & 57.4 & 0.001 \\
\hline Spleen weight, \% & $0.102^{\mathrm{ab}}$ & $0.084^{b}$ & $0.114^{a b}$ & $0.091^{b}$ & $0.162^{\mathrm{a}}$ & $0.088^{b}$ & 0.014 & 0.008 \\
\hline Thymus weight, $\%$ & $0.394^{a}$ & $0.377^{a b}$ & $0.335^{b}$ & $0.481^{a}$ & $0.307^{b}$ & $0.340^{b}$ & 0.078 & 0.004 \\
\hline Fabricius bursa weight, \% & $0.134^{\mathrm{ab}}$ & $0.117^{\mathrm{ab}}$ & $0.179^{a}$ & $0.157^{\mathrm{ab}}$ & $0.159^{a b}$ & $0.100^{b}$ & 0.017 & 0.040 \\
\hline \multicolumn{9}{|c|}{ Chemical composition of meat,\% } \\
\hline Dry matter & 25.1 & 24.9 & 25.0 & 25.0 & 24.9 & 24.9 & 0.064 & 0.215 \\
\hline Crude protein & 19.2 & 19.1 & 19.3 & 19.0 & 18.9 & 19.1 & 0.101 & 0.086 \\
\hline Lipids & 4.72 & 4.75 & 4.58 & 4.73 & 4.81 & 4.64 & 0.071 & 0.294 \\
\hline Ash & 0.973 & 0.993 & 0.990 & 0.987 & 0.983 & 0.990 & 0.012 & 0.879 \\
\hline \multicolumn{9}{|c|}{ Physical characteristics of meat } \\
\hline$\overline{\mathrm{pH}}$ & 5.93 & 6.08 & 6.01 & 6.00 & 6.02 & 5.98 & 0.079 & 0.862 \\
\hline Color, optical density & 0.197 & 0.210 & 0.212 & 0.203 & 0.209 & 0.209 & 0.094 & 0.864 \\
\hline Tenderness $\mathrm{cm}^{2} / \mathrm{g}$ & 9.82 & 10.02 & 10.19 & 10.26 & 9.86 & 10.26 & 0.066 & 0.579 \\
\hline $\mathrm{WHC}, \mathrm{cm}^{2} / \mathrm{g}$ & 17.48 & 18.25 & 17.48 & 17.92 & 17.82 & 17.98 & 0.059 & 0.315 \\
\hline
\end{tabular}

$\mathrm{SEM}=$ Standard error of means, MOS= Mannoligaosacchride, $\mathrm{OTC}=0 \mathrm{xy}$ titeracycline, $\mathrm{pH}=$ hydrogen power; $\mathrm{WHC}=$ Water holding capacity.

a,b,c Differences amona means within a column within each factor not sharina similar superscripts are sianificant $(P<0.05)$. 
affected by the treatments with the exception of the relative weight of the abdominal fat, liver, pancreas (although $F$ value was significant $\mathrm{P} \leq 0.039$ for only pancreas) and intestine. Dressing percentage significantly decreased due to T_0.5 and OTC supplements in comparison to the control group. It was found that the $T 1$ group significantly decreased proventriculus in comparison to the control and MOS groups, and also decreased rate of gizzard in comparison with the control, T_0.5 and T 2 groups. The heart percentage was significantly lower in the T_ 0.5 group than in the control and T_2 groups. Most supplemented groups, except the MŌS group, significantly increased intestinal villi length in comparison to the control one, with the OTC group displaying the greatest effect.

Lymphoid organs such as the spleen, thymus and Fabricius bursa were significantly affected by the dietary supplementations. The MOS group exhibited significantly greater spleen weight than the T_0.5, T_2 and OTC groups. The thymus percentage was greater of the control and T_2 groups than those of the other groups except for
T_0.5 group. The Fabricius bursa of the T_ 1 group was significantly higher than that of only the OTC group.

\section{Meat quality}

Table 4 shows the content of the dry matter, protein, lipids and ash of the meat, as well as the physical traits such as $\mathrm{pH}$, color, WHC and tenderness. These traits were not significantly affected by the different supplementations, but there was a trend $(P \leq 0.086)$ for higher $C P$ of $T_{-} 1$ group than that of MOS group.

\section{Blood biochemical, liver leakage, antibody titer and red blood cells characteristics}

The blood serum biochemical components are shown in Table 5. Different supplements significantly affected serum total protein, globulin, ALKP, ALT, AST, AST/ALT ratio, HI NDV and TAC. It was found that the T_0.5, MOS and OTC groups had a significant increase in the total protein in

Table 5. Serum biochemical, liver leakage markers, antioxidant indices and red blood cell parameters of broiler chickens fed diets supplemented with different concentrations of turmeric, mannanoligosacchride and oxytetracycline

\begin{tabular}{|c|c|c|c|c|c|c|c|c|}
\hline \multirow{2}{*}{ Criteria } & \multirow{2}{*}{ Control } & \multicolumn{3}{|c|}{ Curcumin g/kg diet } & \multirow{2}{*}{ MOS } & \multirow{2}{*}{ OTC } & \multirow{2}{*}{ SEM } & \multirow{2}{*}{$P$ value } \\
\hline & & 0.5 & 1 & 2 & & & & \\
\hline \multicolumn{9}{|l|}{ Serum protein metabolites } \\
\hline Total protein, g/dL & $6.18^{a b}$ & $6.30^{\mathrm{a}}$ & $5.73^{c}$ & $5.93^{b c}$ & $6.40^{\mathrm{a}}$ & $6.40^{\mathrm{a}}$ & 0.066 & 0.001 \\
\hline Albumin, g/dL & 3.30 & 3.27 & 3.12 & 3.12 & 3.07 & 3.07 & 0.103 & 0.628 \\
\hline Globulin, g/dL & 2.88 & 3.02 & 2.60 & 2.80 & 3.33 & 3.32 & 0.143 & 0.032 \\
\hline Albumin to globulin ratio & 1.16 & 1.083 & 1.24 & 1.14 & 0.928 & 0.942 & 0.087 & 0.051 \\
\hline \multicolumn{9}{|c|}{ Liver leakage and antibody markers } \\
\hline Alkaline phosphatase, U/L & $9.25^{c}$ & $10.75^{b c}$ & $12.75^{a}$ & $11.25^{a b}$ & $11.75^{\mathrm{ab}}$ & $11.00^{a b c}$ & 0.431 & 0.008 \\
\hline$A L T, U / L$ & $63.0^{a}$ & $62.0^{\mathrm{a}}$ & $62.3^{\mathrm{a}}$ & $61.8^{a}$ & $60.8^{a}$ & $58.8^{b}$ & 0.512 & 0.001 \\
\hline AST,U/L & $54.3^{a}$ & $50.0^{b}$ & $52.3^{a b}$ & $52.0 \mathrm{ab}$ & $52.3^{a b}$ & $53.3^{a b}$ & 0.731 & 0.017 \\
\hline AST/ALT ratio & $0.862^{a b}$ & $0.806^{b}$ & $0.840^{b}$ & $0.843^{b}$ & $0.863^{a b}$ & $0.909^{a}$ & 0.014 & 0.003 \\
\hline HINDV, Log ${ }^{2}$ & $4.37^{\mathrm{b}}$ & $5.48^{\mathrm{ab}}$ & $6.73^{a}$ & $5.62^{\mathrm{ab}}$ & $5.15^{\mathrm{ab}}$ & $4.12^{b}$ & 0.325 & 0.013 \\
\hline \multicolumn{9}{|l|}{ Antioxidant indices } \\
\hline $\mathrm{TAC}, \mathrm{mmol} / \mathrm{l}$ & $416^{b}$ & $439^{a}$ & $434^{a}$ & $422^{b}$ & $431^{a}$ & $431^{a}$ & 1.43 & 0.001 \\
\hline $\mathrm{MDA}, \mu \mathrm{mol} / \mathrm{l}$ & 10.8 & 11.3 & 11.0 & 11.3 & 10.8 & 11.3 & 0.471 & 0.920 \\
\hline \multicolumn{9}{|l|}{ Red blood cell parameters } \\
\hline RBCs, $\left(10^{6} / \mathrm{mm}^{3}\right)$ & 1.58 & 1.70 & 1.67 & 1.62 & 1.72 & 1.70 & 0.039 & 0.071 \\
\hline $\mathrm{Hgb}, \mathrm{g} / \mathrm{dL}$ & $11.8^{a}$ & $10.8^{a b}$ & $11.8^{a}$ & $10.8^{a b}$ & $10.3^{b}$ & $11.3^{a b}$ & 0.271 & 0.004 \\
\hline PCV,$\%$ & $32.0^{\mathrm{ab}}$ & $32.2^{a b}$ & $33.2^{\mathrm{a}}$ & $32.8^{a}$ & $31.2^{b}$ & $32.2^{a b}$ & 0.381 & 0.008 \\
\hline $\mathrm{MCV}, \mu \mathrm{m}^{3} / \mathrm{RBC}$ & $205^{a}$ & $190^{\mathrm{ab}}$ & $200^{a}$ & $200^{a}$ & $181^{b}$ & $190^{\mathrm{ab}}$ & 4.65 & 0.006 \\
\hline $\mathrm{MCH}, \mathrm{pg}$ & $74.4^{\mathrm{a}}$ & $63.0^{\mathrm{cd}}$ & $70.2^{\mathrm{ab}}$ & $65.4^{\mathrm{bcd}}$ & $60.0^{d}$ & $67.0^{\mathrm{bc}}$ & 1.61 & 0.001 \\
\hline $\mathrm{MCHC}, \%$ & $36.2^{a}$ & $32.8^{b}$ & $34.8^{a b}$ & $32.6^{b}$ & $32.8^{b}$ & $34.8^{a b}$ & 0.721 & 0.002 \\
\hline
\end{tabular}

MOS= Mannoligaosacchride; OTC=Oxytiteracycline; SEM= Standard error of means; ALT= Alanine amino transferase; AST= Aspartate amino transferase; HINDV=haemagglutination inhibition for new castle disease virus; TAC= Total antioxidant capacity; MAD= Malnodialdehyde; Hgb=Hemoglobin; PCV= Packed cell volume; $\mathrm{MCV}=$ Mean cell volume; $\mathrm{MCH}=$ Mean cell hemoglobin; $\mathrm{MCHC}=$ Mean cell hemoglobin concentration.

a,b,c Differences among means within a column within each factor not sharing similar superscripts are significant $(P<0.05)$. 
comparison to the other groups except for the control group. The latter group had also greater total protein than T_ 1 group. Differences in serum globulin were not significant among different means of groups. ALKP was significantly higher for the groups supplemented with T_1, T_2 and MOS in comparison to the control group; the T_1 group showed the greatest effect and T_0.5 and OTC exhibited intermediate values.

The antibiotic supplemented group had significantly decreased ALT in comparison to the other groups, while the T_ 0.5 group had significantly decreased AST in comparison to only the control group. In addition, the AST/ALT ratio of the turmeric groups was significantly lower than that of the OTC group. HINDV was the highest of T_1 group while the lowest was from the control and OTC groups. Most of supplemented groups except that T_ 2 group had significantly higher TACs than that of the control group, with the T_0.5 group exhibiting the greatest TAC. There were no significant differences in MAD among the different groups.

The different treatments had a significant effect on most of the hematological traits except for RBCs $(P \leq 0.071)$. Hgb, PCV, MCV, MCH and $\mathrm{MCHC}$ were the lowest in the MOS group, while $\mathrm{Hgb}, \mathrm{PCV}, \mathrm{MCV}$ of the T_1 group had the highest values. $\mathrm{MCH}$ and $\mathrm{MCHC}^{-}$were the highest in the control group but did not significantly differ from the T_1 group.

\section{DISCUSSION}

The present results indicate that turmeric is a potential source of nutrients, poly-unsaturated fatty acids and antioxidants ${ }^{(38)}$, and T_ 1 improved growth performance and the European production efficiency index. This indicates that $1 \mathrm{~g} / \mathrm{kg}$ turmeric is adequate as an alternative growth promoter that could replace OTC and have a better impact on productive performance than MOS for both FCR and the European production index.

The potential effect of turmeric on growth performance and the production index of broilers are in line with those reported elsewhere $(11,20,39)$. The aforementioned authors concluded that turmeric supplementation at the rate of 1 to 10 $\mathrm{g} / \mathrm{kg}$ improved growth performance of broiler chickens without adverse effects on mortality. In addition, turmeric supplementation at $5 \mathrm{~g} / \mathrm{kg}$ feed improved the growth of chickens exposed to aflatoxins $^{(40,41)}$, and alleviated the negative influences of Eimeria infection ${ }^{(18,19,42)}$ and of heat stress ${ }^{(39)}$. These potential effects of turmeric could be attributed to its curcuminoids ( 3 to $5 \%$, as found in turmeric powder), bisdemethoxy curcumin and demethoxy curcumin, the principle active compounds in turmeric ${ }^{(43)}$. These compounds show a wide spectrum of biological activities including antioxidant, antibacterial, antifungal, antiprotozoal, antiviral, anticoccidial and anti-inflammatory properties, digestion- and absorption-enhancing effects, and protection effects against coccidiosis and toxins ${ }^{(5,19,44)}$. Turmeric also improves liver and bile functions through increased bile secretions, protects the stomach from ulcers and reduces liver toxins. These improvements can enhance digestion, metabolic processes and nutrient utilisation for growth through stimulation of protein synthesis by the chicken enzymatic system ${ }^{(6,11)}$. Turmeric has been observed to enhance the intestinal lipases, amylase, trypsin and chymotrypsin secretions ${ }^{(45)}$. This is similar to our findings regarding the increase in the length and width of villi in the intestinal, which are also similar to other findings ${ }^{(45)}$. Therefore, the improvement in the growth performance due to turmeric supplementation to broilers' diets can be partly attributed to improving the ecology and function of the digestive tract of chickens. On the other hand, turmeric did not show constant effects on growth performance as had been reported ${ }^{(21)}$. No significant positive effect of turmeric powder at between 3.03 and $10 \mathrm{~g} / \mathrm{kg}$ diet on the growth performance of broiler chickens ${ }^{(9,12)}$. This inconsistency in the reviewed results can be attributed to the different qualities of feed, breeder and age of the broilers, statistical design, doses of turmeric and the sanitary and environmental conditions. The improved production index by $15.6 \%$ due to inclusion of turmeric powder at $1 \mathrm{~g} / \mathrm{kg}$ is in the range cited in the literature of $1.5 \%{ }^{(39)}$ and $11.8 \%{ }^{(6)}$ when turmeric was supplemented at $5 \mathrm{~g} / \mathrm{kg}$ feed.

Turmeric, particularly at $1 \mathrm{~g} / \mathrm{kg}$ feed, induced adaptive changes in the different body organs. The decreased proventriculus and gizzard and increased intestinal villi length indicated enhanced digestive function that can explain the increased performance, meat protein and somewhat 
decrease in meat lipid of the broilers on the T_1 treatment. On the other hand, turmeric at 1 and 2 $\mathrm{g} / \mathrm{kg}$ diet had no negative effects on carcass traits. Meat quality is an important concept in broiler production nowadays and improved postharvest quality and shelf life is essential(32). The present findings indicate that turmeric is a beneficial feed additive due to phytochemicals, such as curcumin, AR-turmerone, methylcurcumin and other active compounds that could improve carcass quality and reduce spoilage ${ }^{(1,5)}$. This increase in the quality of the carcass traits of broilers could be attributed to its antimicrobial effect, which improves the shelf life of the carcasses ${ }^{(1,6,11)}$.

Despite the absence of a significant effect of turmeric in this study on the relative weight of abdominal fat, liver and intestines, there was a numerical decease in percentage abdominal fat of $11.7 \%$ and $16.5 \%$ and in liver of 8.5 and $4.7 \%$ due to turmeric supplementation at 1 and $2 \mathrm{~g} / \mathrm{kg}$, respectively. The positive effect of turmeric in abdominal fat and liver could be attributed to its negative influence on liver fatty acid synthesis as manifested by an increase in meat CP and the decrease in meat lipid of T_1 group. In literature, liver triacylglycerol and plasma triacylglycerol in the VLDL fraction and liver cholesterol significantly decreased, but the activity of hepatic acyl-CoA oxidase increased ${ }^{(9,46)}$. In addition, turmeric at a rate of $3 \mathrm{~g} / \mathrm{kg}$ feed reduced the meat fat content and increased the carcass quality of broilers ${ }^{(11,47,48)}$.

In partial agreement with the present results, turmeric supplementation at $5 \mathrm{~g} / \mathrm{kg}$ feed did not significantly affect percent dressing, liver, gizzard and heart, but significantly increased the proventriculus $^{(6)}$. In addition, turmeric at the same dose significantly increased percent dressing, weight of the breast and thigh, but did not affect percent liver, heart and gizzard(6). In other studies, turmeric supplementation did not significantly affect the weight of the carcass, heart, pancreas or intestine ${ }^{(9)}$, gall bladder(11), the ready-to-cook carcass, liver, pancreas, heart, gizzard, proventriculus, abdominal fat and length of the entire small intestinal, duodenum, jejunum and ileum(12). However, turmeric decreased the abdominal fat and liver percentages $^{(9,11)}$ and increased percentage of the entire small intestinal and the ileum weight ${ }^{(12)}$.

The effect of turmeric, MOS and OTC on meat quality are in partial agreement with those reported elsewhere ${ }^{(11)}$, who showed that curcuma longa did not affect crude protein or extracts of breast and thigh meat as well as organoleptic tests (smell, flavour, colour and tenderness).

Lymphoid organs, antibody level, antioxidant status and blood metabolites are a good markers of health status of the animal. The impact of turmeric concentrations on lymphoid organs indicates that different concentrations of turmeric did not affect spleen, thymus and Fabricius bursa percentages, but MOS increased percent spleen and decreased thymus and did not significantly affect Fabricius bursa and 28-d HINDV titer in comparison with the control and antibiotic groups. In the literature, the inclusion of turmeric powder increased the spleen weight and did not affect the Bursa and thymus weight index ${ }^{(11)}$, spleen and bursa of Fabricius ${ }^{(9,12)}$ and relative weight of the spleen, bursa or thymus ${ }^{(20)}$. These results reveal that turmeric is a safe phytogenic feed supplement for chickens and may enhance their immune response as measured by specific antibody titres, as reviewed by others ${ }^{(5)}$.

The changes in serum metabolites indicate that, except for the decrease in serum total protein, turmeric supplementation at different doses did not affect serum albumin, globulin and albumen to globulin and indices of hepatocellular leakage (ALT, AST and AST/ALT). There were, however, numerical decreases in the AST and AST/ALT ratio, which show a potential decease in hepatocellular leakage markers that could be attributed to the significant increase in TAC (antioxidants index) of broilers fed turmeric supplemented-diets. Similarly, serum ALT and AST were not affected by turmeric powder ${ }^{(49)}$. In addition, turmeric powder at 0.6 and 0.9 alleviated the negative effect of aflatoxin $B_{1}$ on serum total protein, albumin and globulin, boosted antioxidant defence enzymes, e.g. catalase and superoxide dismutase, and decreased $M^{2}{ }^{(2)}$. The levels of liver enzymes (ALT and ALKP) were substantially reduced by feeding broilers turmeric powder ${ }^{(22)}$. On the other hand, turmeric at $5 \mathrm{~g} / \mathrm{kg}$ feed did not affect serum total protein, albumin, globulin, ALKP, ALT and AST enzymes ${ }^{(20)}$.

The increase in the Hgb and PCV of broilers supplemented with turmeric at $1 \mathrm{~g} / \mathrm{kg}$ feed indicates an improvement in health status. This can be attributed to the antioxidant capacity of turmeric and its digestive-enhancing effect that 
may improve iron absorption. Similar results were reported by for RBCs ${ }^{(11)}$ and for PCV ${ }^{(12)}$. Also, found that turmeric improved the health status of broilers ${ }^{(20)}$. In accordance with the present results, no mortality up to $35 \mathrm{~d}$ of age in broilers was observed when turmeric was supplemented at $0.5 \%$ in the broiler $\operatorname{diet}^{(6)}$, and less mortality was observed at $0.1 \%$ inclusion $^{(39)}$.

It was found that turmeric at $1 \mathrm{~g} / \mathrm{kg}$ feed had effects comparable to MOS and OTC on growth, dressing percentage and lymphoid organs, and was better by $8.7 \%$ than MOS for FCR. The lower feed utilization of the MOS group might have been due to their lowest villi length. OTC induced the highest increase in intestinal villi, with no difference in FCR and production index from the turmeric groups. The effect of OTC seems to be related to the anti-inflammatory action of OTC rather than to its antibiotic effect ${ }^{(26,50,51)}$. On the other hand, MOS and OTC increased serum total protein compared to the intermediate and highest turmeric doses. These results indicated that turmeric had antibiotic-like effects due to its antimicrobial and anti-inflammatory effects.

\section{CONCLUSION AND IMPLICATIONS}

Turmeric can be used at $1 \mathrm{~kg} / \mathrm{t}$ feed as a phytogenic feed additive as an alternative to OTC or MOS without negative effects on the productive and economic traits of broilers. There were no differences from using OTC and MOS, while there was an increase in the European production efficiency index and the broilers' health status.

\section{ACKNOWLEDGMENTS}

This project was funded by the Deanship of Scientific Research (DSR) at King Abdulaziz University, Jeddah, under grant G-1436/155/205. The authors, therefore, acknowledge with thanks DSR for technical and financial support.

\section{LITERATURE CITED}

1. Windisch WM, Schedle K, Plitzner C, Kroismayr A. Use of phytogenic products as feed additives for swine and poultry. J Anim Sci 2008; 86:140-148.

2. Ahmadi F. Effect of Turmeric Curcumin longa powder on performance, oxidative stress state and some of blood parameters in broilers fed on diets containing aflatoxin. Global Vet 2010;5:312-317.
3. Attia YA, Zeweil HS, Alsaffar AA, El-Shafy AS. Effect of nonantibiotic feed additives as an alternative to flavomycin on broiler chickens production. Archiv Geflügelk_2011;75:40-48.

4. Attia YA, Al-Harthi MA. Nigella seed oil as an alternative to antibiotic growth promoters for broiler Chickens. Europ Poult Sci 2015; 79:DOI, 10.1399/eps.2015.80.

5. Eevuri TR, Putturu R. Use of certain herbal preparations in broiler feeds - A review, Vet World 2013;6:172-179.

6. Durrani FR, Ismail M, Sultan A, Suhail SM, Chand N, Durran Z. Effect of different levels of feed added turmeric Curcuma longa on the performance of broiler chicks. J Agric Biol Sci 2006; 1:9-11.

7. Nasir Z, Grashorn MA. Echinacea, A potential feed and water additive in poultry and swine production. Arch Geflügelk 2009; 73:227-236.

8. Nasir Z, Grashorn MA. Effects of Echinacea purpurea and Nigella sativa supplementation on broiler performance, carcass and meat quality. J Anim Feed Sci 2010; 19:94-104.

9. Nouzarian R, Tabeidian SA, Toghyani M, Ghalamkari G, Toghyani $M$. Effect of turmeric powder on performance, carcass traits, humoral immune responses, and serum metabolites in broiler chickens. J Anim Feed Sci 2011;20:389-400.

10. Kiuchi F, Goto $Y$, Sugimoto N, Akao N, Kondo K, Tsuda Y. Nematocidal activity of turmeric, Synergistic action of curcuminoids. Chem Pharm Bull 1993; 41:1640-1643.

11. Al-Sultan SI. The effect of Curcuma longa turmeric on overall performance of broiler chickens. Int J Poult Sci 2003;2:351-353.

12. Sadeghi GH, Karimi A, Padidar JSH, Azizi T, Daneshmand A. Effects of cinnamon, thyme and turmeric infusions on the performance and immune response in of 1-to 21-day-old male broilers. Braz J Poult Sci 2012;14:15-20.

13. Osawa $\mathrm{T}$, Sugiyama $\mathrm{Y}$, Inayoshi $\mathrm{M}$, Kawakisi $\mathrm{S}$. Anti-oxidative activity of tetrahydrocurcuminoids. Biotech Biochem 1995; 59:1609-1616.

14. Wuthi-Udomler M, Grisanapan W, Luanratana O, Caichompoo W. Anti-fungal activities of plant extracts. South East Asian J Trop Med Public Health 2000;31: 178-182.

15. Alia $B H$, Marrif $\mathrm{H}$, Noureldayemc $\mathrm{SA}$, Bakheitd AO, Blunden $\mathrm{G}$. Biological properties of curcumin, a review. NPC 2006; 1:509521.

16. Soni, KB, Lahiri M, Chackradeo P, Bhide SV, Kuttan R. Protective effect of food additives on aflatoxin-induced mutagenicity and hepatocarcinogenicity. Cancer Letters 1997; 115:129-133.

17. Allen PC, Fetterer RH. Recent advances in biology and immunobiology of Eimeria species and in diagnosis and control of infection with these coccidian parasites of poultry. Clin Microbiol Rev 2002; 15:58-65.

18. Lee SH, Lillehoj HS, Jang SI, Kim DK, Ionescu C, Bravo D. Effect of dietary curcuma, capsicum, and lentinus on enhancing local immunity against Eimeria acervulina infection. J Poult Sci 2010; 47:89-95.

19. Abou-Elkhair R, Ahmed HA, S. Selim S. Effects of black pepper ( Piper nigrum), turmeric powder (Curcuma Longa) and coriander seeds (Coriandrum sativum) and their combinations as feed additives on growth performance, carcass traits, some blood parameters and humoral immune response of broiler chickens. Asian-Austral J Anim Sci 2014;27:847-854.

20. Mehala C, Moorthy M. Production performance of broilers fed with aloe vera and Curcuma longa (turmeric). Int J Poult Sci 2008; 7:852-856. 
21. Emadi $M$, Kermanshahi $\mathrm{H}$. Effect of turmeric rhizome powder on the activity of some blood enzymes in broiler chickens. Int J Poult Sci 2007;6:48-51.

22. Hooge DM. Meat-analysis of broiler chicken pen trials evaluating dietary mannan oligosaccharide 1993-2003. Int J Poult Sci 2004; 3: 163-174.

23. Attia YA, Abd El Hamid EA, Ismaiel AM, El Nagar ASh. The detoxication of nitrate by two antioxidants or a probiotic and the effects on blood and seminal plasma profiles and reproductive function of NZW rabbit bucks. Anim 2013; 7:591-601.

24. Ogunwole OA, Abu OA, Adepoju IA. Performance and carcass characteristics of broiler finishers fed acidifier based diets. Pak J Nut 2011;10:631-636.

25. Khadem A, Soler L, Everaert N, Niewold TA. Growth promotion in broilers by both oxytetracycline and Macleaya cordata extract is based on their anti-inflammatory properties. $\mathrm{Br} J$ Nut 2014; 112:1110-1118.

26. Official methods of analysis of AOAC International. Official Methods of Analysis 16th ed. 2007.

27. Janssen WM. European table of energy values for poultry feedstuffs, $3^{\text {rd }}$ ed. Wageningen, The Netherlands. 1989.

28. Radwan SS. Coupling of two dimension thin layer chromatography with gas chromatography for the quantitative analysis of lipids glasses and their constituent fatty acids. J Chromatography Sci 1978;16:538-542.

29. Blainski A, Lopes GC, De Mello JCP. Application and analysis of the folin ciocalteu method for the determination of the total phenolic content from Limonium brasiliense L. Molecules 2013; 18:6852-6865.

30. Benzie IF, Strain JJ. Ferric reducing/antioxidant power assay, direct measure of total antioxidant activity of biological fluids and modified version for simultaneous measurement of total antioxidant power and ascorbic acid concentration. Meth Enzymol 1999;299:15-27.

31. National Research Council, NRC. Nutrient Requirements of Poultry. 9th ed. Washington DC: National Academic Press; 1994.

32. Attia YA, El-Tahawy WS, Abd El-Hamid AE, Nizza A, El-Kelway MI, Al-Harthi MA, Bovera F. Effect of feed form, pellet diameter and enzymes supplementation on carcass characteristics, meat quality, blood plasma constituents and stress indicators of broilers. Archiv Tierzucht 2014;57:1-14.

33. Attia YA, Abd Al-Hamid AE, Ibrahim MS, Al-Harthi MA, Bovera F, El-Naggar A Sh. Productive performance, biochemical and hematological traits of broiler chicks supplemented with propolis, bee pollen, and mannan oligosaccharides continuously or intermittently. Livestock Sci 2014;164:87-95.

34. Snyder DB, Marquardt WW, Mallinson ET, Savage PK, Allen DC. Rapid serological profiling by enzyme-linked immunosorbent assay. III. Simultaneous measurements of antibody titers to infectious bronchitis, infectious bursal disease, and Newcastle disease viruses in a single serum dilution. Avian Disease 1984; $28: 12-24$

35. Bancroft JD, Layton C, Suvarna SK. Bancroft's theory and practice of histological techniques. $7^{\text {th }}$ ed, Churchill Livingstone: Elsevier; 2013.
36. Aptekmann K, Artoni S, Stefanini M, Orsi M. Morphometric analysis of the intestine of domestic quails (Coturnix coturnix japonica) treated with different levels of dietary calcium Anat Histol Embryol 2001;30:277-280.

37. SAS, Institute. User's guide. Ver $9.2,2^{\text {nd }}$ ed. SAS institute Inc. Cary NC. USA. 2009.

38. Gur S, Turgat-Bubk D, Gur N. Antimicrobial activates and some fatty acids of turmeric, ginger root and linseed used in the treatment of infectious diseases. World J Agric Sci 2006;2:439442.

39. Kumar M, Choudhary RS, Vaishnav JK. Effect of supplemental prebiotic, probiotic and turmeric in diet on the performance of broiler chicks during summer. Ind J Poult Sci 2005;40:137-141.

40. Yarru LP, Settivari RS, Gowda NKS, Antoniou E, Ledoux DR, Rottinghaus GE. Effects of turmeric Curcuma longa on the expression of hepatic genes associated with biotransformation, antioxidant, and immune systems in broiler chicks fed aflatoxin. Poult Sci 2009;88:2620-2627.

41. Gowda NKS, Ledoux DR, Rottinghaus GE, Bermudez AJ, Chen YC. Efficacy of turmeric Curcuma longa, containing a known level of curcumin, and a hydrated sodium- calcium aluminosilicate to ameliorate the adverse effects of aflatoxin in broiler chicks. Poult Sci 2008; 87:1125-1130.

42. Abbas RZ, I qbal Z, Khan MN, Zafar MA, Za, MA. Anticoccidial activity of Curcuma longa L. in broilers. Braz Arch Biol Technol 2010;53:63-67.

43. Roughley PJ, Whiting DA. Experiments in the biosynthesis of curcumin. J Chem Soc Perkin Trans 1973;1:2379-2388.

44. Masuda T, Maekawa T, Hidaka K, Bando H, Takeda Y, Yamaguchi $\mathrm{H}$. Chemical studies on antioxidant mechanism of curcumin, analysis of oxidative coupling products from curcumin and linoleate. J Agric Food Chem 2001;49:2539-2547.

45. Rajput N, Muhammah N, Yan R, Zhong X, Wang T. Effect of dietary supplementation of curcumin on growth performance, intestinal morphology and nutrients utilization of broiler chicks. J Poult Sci 2012;50:44-52.

46. Asai A, Miyazawa T. Dietary curcuminoid prevent high-fat induced lipid accumulation in the rate liver epididymal adipose tissue. J Nutr 2001;131:2932-2935.

47. Samarasinghe K, Wenk C, Silva KSFT, Gunasekera JMDM. Turmeric Curcuma longa root powder and mannanoligosaccharides as alternatives to antibiotics in broiler chicken diets. AsianAust J Anim Sci 2003; 16:1495-1500.

48. Emadi $M$, Kermanshahi $H$. Effect of turmeric rhizome powder on performance and carcass characteristics of broiler chickens. Int J Poult Sci 2006; 5: 1069-1072.

49. Reddy T. Effect of herbal preparations on the promoters. Poultry fortune performance of broilers [M.V.Sc., thesis]. Sri Venkateswara Veterinary University, Tirupathi. India. 2010.

50. Dibner JJ, Richards JD. Antibiotic growth promoters in agriculture, history and mode of action. Poult Sci 2005; 84:634-643.

51. Niewold TA. The non-antibiotic anti-inflammatory effect of antimicrobial growth promoters, the real mode of action? A hypothesis. Poult Sci 2007;86:605-609. 